\title{
Psychology of Creativity and Innovation in Engineering
} and Business Curriculum

doi:10.2478/mape-2021-0035

Date of submission to the Editor: 03/2021

Date of acceptance by the Editor: 05/2021

MAPE 2021, volume 4, issue 1, pp. 387-394

Michalene Eva Grebski

ORCID ID: 0000-0002-3487-4473

Colorado Mesa University, USA

Wes Grebski

The Pennsylvania State University, USA

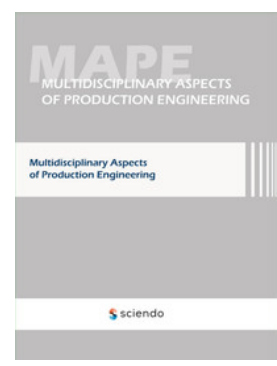

\section{INTRODUCTION}

In modern times economic prosperity depends on creativity and innovativeness of the workforce (Maradana et al., 2017). The foundation of the modern economy relies on intellectual property and human capital (Lopez-Leyva \& Mungaray-Moctezuma, 2017).

Creativity involves the generation of new ideas for solving problems. Creativity can range from scientific discovery to a new business model, new marketing strategy or new work of art. Creativity is also helpful in solving personal problems, interpersonal conflicts, family issues and many others (Psychplogy toda 2018).

Innovative potential is the individual capacity to generate novel useful ideas in unique boundary-breaking ways. Those ideas may inspire others to produce growth and development. There are conditions and practices strengthening innovative potential or suppressing innovative potential (Miron et al., Scott \& bruce, 1994, Yuan \& Woodman 2010). We are subject to those conditions from early childhood until retirement. Therefore, fostering practices conducive to strengthening and nurturing innovative potential are important in our lives. Innovative state-of-the-art companies are effectively creating conditions strengthening innovative potential (Kanter 1982). However, there are many companies which do not recognize these opportunities. In addition, our school system from kindergarten through Grade 12 (or even university level) operates under conditions which suppress innovative potential. Human personality is the combination of adaptive and innovative personality. School systems as well as family values nurture the adaptive personality (Kwang \& Rodrigues 2002). By nurturing the adaptive personality, the educational process is easier to manage. During the educational process, the innovative personality is harmed rather than developed. There are some individuals who are resilient to the harm and maintain an innovative personality and do not lose their innovative potential. Innovative potential cannot be measured per se and can only be assessed by innovative behavior and future outcomes. 


\section{COURSE OBJECTIVES}

The objective of the course is to develop and nurture creativity and innovation skills. Creativity and innovation skills are foundations for success in all areas (Art, Business, Engineering, Entrepreneurship, Marketing) as well as personal and family life (Surowiecki 2004). The course is designed to be beneficial for Psychology graduates who wish to develop their psychology expertise in the theory and practice of creativity and innovation. The course will also be suitable for Art, Business and Engineering students. The course will focus on the methodology of increasing creative behavior of individuals, groups and organizations (Sternberg \& Lubart 1999). Class discussion will focus on journal articles. The course will be a psychological study of creativity including the theories of creativity, process of creativity as well as motivation, creative thinking and problem-solving skills. The course will also address the characteristics of innovative people as well as blocks to creativity slowing down the creative process (Grabowska et al., Wolniak et al. 2018). The course covers three distinctive approaches.

- Individual innovations

(How can individual innovative behavior be enhanced?)

- Team innovations

(Compositions and management of innovative teams)

- Organizational innovations

(How can an organization support innovative behavior of individuals and teams?)

The course will provide a framework for a creative innovative approach in developing ideas into reality. In the group project, the class will be divided into innovative teams. Each innovative team will create a group portfolio and conduct a presentation describing the completed project.

\section{Course Audience:}

This course will be developed as an elective course for students in the following majors.

\section{- Psychology}

The course is using the concept and applied methodology from social psychology, cognitive psychology, individual differences and work psychology. The course is a big picture approach from problem identification to solution implementation.

\section{- Engineering}

Engineering students will get an understanding and appreciation for exploring an intelligent fast failure methodology in solving technical problems. The course will help them to adopt a risk-taking culture as well as the ability to function well on multidisciplinary and multicultural teams. Students will learn to identify the problems and opportunities before anyone else discovers them. 


\section{- Business Administration}

Business students will learn to successfully work on multidisciplinary and multicultural teams. The course will promote a risk-taking culture as well as intelligent fast failure methodology. The course will provide guidance and methodology to identify opportunities and problems before anyone else can see them.

- Art

Art students will become aware of the big picture of creativity. They will be encouraged to take bold steps to identify the opportunities and make their contributions. Students will also learn to work on multidisciplinary and multicultural teams. Working on innovative teams with business, engineering and psychology students will add another dimension to art education. Students will learn the procedure for brainstorming as well as other methods for generating and evaluating new ideas.

\section{EXPECTED LEARNING OUTCOMES}

After the completion of the course, students will be able.

- To describe the characteristics of innovative behavior in individuals.

- To describe the characteristics of innovative teams.

- To describe the characteristics of innovative organizations.

- To describe analysis and research methods for studying innovative behavior at different levels of the organization.

- To analyze different levels of innovative behavior at different levels of an organization.

- To state the factors influencing behavior at different levels of opportunities.

- To create an innovative solution to a given problem.

- To use a systematic approach for moving from a problem to a proposed solution and to commercialization.

- To work effectively on multidisciplinary diverse innovative teams.

- To state the differences between adaptive style and creative style.

- To identify their own creative style.

- Know how to manage the resistance.

- Demonstrate self-determination, codetermination and solidarity.

- Have problem solving ability.

- Know how to apply Intelligent Controlled Failure Method

- Know Ideation Methods

- Apply Design Thinking

- Know how to Evaluate Ideas.

\section{EXPECTED ATTITUDE OUTCOMES}

At the end of the course, the student expected to

- View every new problem as a new opportunity. 
- Seek opportunities to innovate.

- Apply creative thinking in everyday life.

- Be aware of their creative talent(s).

- Have a higher confidence level.

- Feel the sense of power.

(I am in the driver's seat.)

- Feel capable to make positive contributions to the world.

- Have a positive outlook for the future.

- Feel that creativity is fun. (Creativity is not work.)

- Appreciate diversity and teamwork.

- Know how to keep Idea Journal.

- Appreciate creative diversity.

- Have ability to make choices.

- Know how to talk to customers .

- Know yourself.

- Understand life phases and transformation.

\section{COURSE CONTENT}

The course will address different topics each week with the student presentations at the end of the semester.

\begin{tabular}{|l|l|}
\hline Schedule & \multicolumn{1}{|c|}{ Topics } \\
\hline Week 1 & $\begin{array}{l}\text { Introduction, course overview, class expectations, grading procedure, team } \\
\text { formation }\end{array}$ \\
\hline Week 2 & $\begin{array}{l}\text { Adaptive and innovative personalities/individual innovation. Intelligent } \\
\text { Controlled Failures, Idea Journal, Creative Divergence and Convergent. }\end{array}$ \\
\hline Week 3 & $\begin{array}{l}\text { Innovativeness of the team/group innovations (Brainstorming and idea } \\
\text { evaluation) Creative Divergence, Ideas Evaluation Methods, Critical Problem- } \\
\text { Solving Process }\end{array}$ \\
\hline Week 4 & $\begin{array}{l}\text { Why multidisciplinary diverse teams are more creative and innovative. } \\
\text { Creative Diversity, Paradox of Structure, }\end{array}$ \\
\hline Week 5 & $\begin{array}{l}\text { Conditions enhancing or inhibiting creativity and innovativeness, Paradox of } \\
\text { Structure, Building Self Determination Codetermination and Solidarity. }\end{array}$ \\
\hline Week 6 & $\begin{array}{l}\text { Creativity and innovativeness within organizations, Managing the Resistance. } \\
\text { Intrinsic motivation, Decentralization and Innovative Culture }\end{array}$ \\
\hline Week 7 & $\begin{array}{l}\text { Creativity, innovativeness and problem-solving, Ideation Methods, Design } \\
\text { Thinking, Making Choices. } \\
\text { Accessing knowledge while decision-making. }\end{array}$ \\
\hline Week 8 & $\begin{array}{l}\text { Motivation and innovative behavior, Measuring Creative Output, Knowing } \\
\text { Yourself }\end{array}$ \\
\hline Week 9 & $\begin{array}{l}\text { Social and cultural factors of creativity and innovativeness, Life Phases } \\
\text { Transformation }\end{array}$ \\
\hline Week 10 & Enhancing creativity and innovativeness \\
\hline Week 11 & $\begin{array}{l}\text { Cognition factors/importance of subject knowledge } \\
\text { Generating and protecting intellectual property, Talking to costumers. }\end{array}$ \\
\hline Week 12 & Student project presentations \\
\hline Week 13 & Student project presentations \\
\hline Week 14 \\
\hline Week 15 \\
Reflecting, sharing, brainstorming and idea generation for improvement of this \\
\hline
\end{tabular}




\section{STUDENTS WEEKLY PROJECT ASSIGNMENTS \\ Weekly Projects and Assignments}

1. Trash-to-Treasure Project

(Use trash that you can find in your house and create something useful or a piece of artwork.)

2. Make something from an old/used car tire.

3. List the five biggest failures which took place in your lifetime.

4. List the ten biggest successes which took place in your lifetime. (Look for the correlations between your successes and failures.)

5. Use a sheet of paper (8.5"x11") and build a bridge between two paper cups (apart).

(Measure the load capacity of that bridge by counting how many washers (provided by the instructor) can be put in the middle of the bridge before it will collapse.)

6. Build the tallest tower using 30 paper cups provided by the instructor.

7. Write the five most innovative ideas that you had in your lifetime. (Describe them in as much detail as possible.)

8. Write the five entrepreneurial opportunities that you have had in your lifetime.

(Describe them in as much detail as possible.)

9. Describe any bold act of defiance that you took in your lifetime.

10. Reflect on your life and identify different phases through which you went. (What was the turning point of each phase?)

11. Write five ideas that can be implemented in your community which will enhance the quality of life in your community.

12. Write five innovative ideas to lower your carbon footprint.

13. Write three innovative ideas to lower your energy consumption.

\section{INNOVATION PROJECT}

\section{Improve Your Community and the World Innovative Projects}

This is a group project to be completed during the first twelve weeks of classes. The class will be divided into multidisciplinary diverse teams. Each team will contain approximately five students. Teams can select one of the projects suggested by the instructor or can develop their own project.

The idea of improving the world must be developed and described in great detail. Improving the world is being interpreted as making something better, more positive or human friendly. Making something better means something goes smoother, faster, less expensive, less labor-intensive, more functional and userfriendly, less energy-intensive, safer, etc.

Students will be allowed twelve weeks to complete the project, prepare a written report and make a twenty-minute oral presentation.

Students will report not only outcomes, but also the process and procedure. Intelligent fast-failure methodology is recommended. 
Students will be graded based on applying creativity and innovative behavior rather than just the project outcome. Project will be peer-reviewed by other students.

\section{LIST OF PROPOSED TOPICS}

1. Energy efficient people transportation device for the future

2. Energy efficient low-cost housing

3. Harvesting and storing solar energy

4. Lowering the carbon footprint to prevent global warming

5. Water filtration system for underdeveloped countries

6. Futuristic healthcare and health monitoring system

7. Futuristic marketing and shopping

8. Futuristic mental healthcare and mental health monitoring system

9. Futuristic farming method

10 . Food production for the $22^{\text {nd }}$ century

11. Energy generation and storage

Students may add their own topic into the list after discussing it with the instructor.

\section{Guidelines for Peer-review of the Student's Innovative Proposal}

Criticism and feedback provided to other students need to have the following components.

- Positive spin

(Describe the strengths of the project. Do this in a positive and constructive tone.)

- Assessment of uniqueness (Comment on the unique aspects of the project.)

- Suggestions for improvement (Be constructive and positive.)

- Assessment of educational values

(Describe what you learned from the project. Use a positive tone)

\section{Grading Procedure}

\begin{tabular}{|l|c|}
\hline Method of Evaluation & Percentage \\
\hline Class participation & $10 \%$ \\
\hline Weekly assignments and peer review & $30 \%$ \\
\hline $\begin{array}{l}\text { Improve the World Group Project } \\
\text { (including written report and oral presentation) }\end{array}$ & $40 \%$ \\
\hline Mid-term Exam & $10 \%$ \\
\hline Final Exam & $10 \%$ \\
\hline
\end{tabular}

\section{Honors Code}

All students are expected to be familiar and respect the University Honors Code. 


\section{Technology Expectations}

All students are expected to regularly access the University email system.

\section{CONCLUSIONS}

The proposed curse is a step forward in promoting and nurturing creativity and innovativeness in higher education. A multidisciplinary approach makes the course very unique. After the course is offered for 1 year, the modification of course content will be implemented as a part of continues quality improves process.

\section{REFERENCES}

Maradana, R.P., Pradhan, R.P., Dash, S. et al. (2017) Does innovation promote economic growth? Evidence from European countries. J Innov Entrep 6, 1/2017. https://doi.org/10.1186/s13731-016-0061-9

Lopez-Leyva, S., \& Mungaray-Moctezuma, A. B. (2017) Knowledge - Based Economy as a Foundation for the Economic Development of Countries. Management Dynamics in the Knowledge Economy, 5(4), pp. 481-501. https://doi.org/10.25019/MDKE/5.4.02

Psychology Toda. (2018) Everyday Creativity. [online] Available at: http://www.psychologytoday.com/us/articales /200911/everyday-creativity [Accessed 3 July 2018]

Miron, E.; Erez, M.; Naveh, E.: (2004) Do personal characteristics and cultural values that promote innovation, quality and efficiency complete or complement each other? In: Journal of Organizational Behavior 25, Nr. 2, pp. 175-199.

Scott, S.G.; Bruce, R.A.:(1994) Determinant of Innovative Behavior: A Path Model of Individual Innovation in the Workplace. In: The Academy of Management Journal 37, Nr. 3, pp. 580-607

Yuan, F.; Woodman, R.W.: (2010) Innovative Behavior in the workplace: The Role of Performance and Image Outcome Expectations. In: The Academy of Management Journal 53, Nr. 2, pp. 323-342

Kanter, R.M.: (1982) The middle manager as innovator. In: Harvard business review 60 Nr. 4, pp. 95-105

Kwang, N. A., \& Rodrigues, D. (2002) A Big-Five Personality Profile of the Adaptor and Innovator. The Journal of Creative Behavior, 36(4), pp. 254-268.

Surowiecki, J., (2004) The Wisdom of Crowds: Why the Many are Smarter than the Few and How Collective Wisdom Shapes Business, Economies, Societies and Nations. New York: Doubleday. ISBN: 978-0-385-50386-0.

Sternberg, R.J. \& Lubart, T.I. (1999) The Concept of Creativity: Prospects and Paradigm. In R.J. Sternberg (ed.), Handbook of Creativity, Cambridge: Cambridge University Press, pp. 3-15

Grabowska, S., Grebski, M.A., Grebski, W. and Wolniak, R., (2019) Introduction to Engineering Concepts from a Creativity and Innovativeness Perspective. Middletown, Delaware: KDP Publishing. ISBN: 9781694859075.

Wolniak, R. and Grebski, M. (2018) Promoting Creativity and Innovativeness in Education, $1^{\text {st }}$ ed. New York: CreateSpace Independent Publishing Platform. ISBN: 978-1721903054. 
Abstract: The paper describes the development of a new course. Psychology of innovation, which is in the process of being approved as an elective course for four different majors: engineering, business, psychology, and art. The paper describes the course content, course educational objective, weekly assignments and projects. The new course is expected to be approved and implemented in the Fall 2021 Semester. The Course is expected to strengthen innovative potential of students from four different majors.

Keywords: Psychology innovation, innovative potential, students 